\title{
Guillain-Barré Syndrome Associated with SARS-CoV-2 Infection: A Case Report
}

\author{
Mohammad Darvishi (1), Hamze Shahali (1), Azade Amirabadi Farahani (2)
}

(1) Aerospace and Sub-Aquatic Medical Faculty, Aja University of Medical Sciences, Tehran, Iran; (2) Department of Medical Pathology, Medical Faculty, Tehran University of Medical Sciences, Tehran, Iran.

This article is distributed under the terms of the Creative Commons Attribution Noncommercial License (CC BY-NC 4.0) which permits any noncommercial use, distribution, and reproduction in any medium, provided the original author(s) and source are credited.

\begin{abstract}
A 56-year-old man was referred to the emergency department for the subacute onset of and weakness in the lower extremities, paraesthesia and pain. He was diagnosed with SARS-CoV-2 pneumonia and then, he received the necessary treatment according to national protocol. Radiographic, laboratory, and electroneurographic findings indicated an acute polyradiculoneuritis with prominent demyelination and suggesting the diagnosis of GuillainBarr syndrome associated with COVID-19 infection.
\end{abstract}

Key Words: COVID-19; SARS-CoV-2; Guillain-Barré syndrome.

Eur J Transl Myol 31 (3): 9494, 2021 doi: 10.4081/ejtm.2021.9494

Nowadays, world healthcare systems are facing the pandemic of the severe acute respiratory coronavirus 2 (SARS-COV-2) and its associated disease, named cronavirus disease 19 (COVID-19). This virus is a new human pathogen, and currently, there are no specific treatment options or vaccinations. ${ }^{1}$ COVID-19 mostly affects the respiratory system, ranging from mild flu-like symptoms to severe pneumonia, but extrarespiratory multisystemic involvement has also been reported. ${ }^{2} \mathrm{Li}$ et al. $^{3}$ recently described the neuroinvasive potential of COVID-19 and at the time of this writing, at least two similar cases of acute dysimmune neuropathy were reported associated with SARS-CoV-2 Infection., ${ }^{4,5}$ Rapid transmission and possible complications needs early accurate diagnosis and close follow up. Emergency medical Service and Aeromedical Transportion teams (as flight crew), are at higher risk and taking care of their health and protect them (as the first line of patient's contact) from mortality and morbidity, are very important.

\section{Materials and Methods}

\section{Case presentation}

A 56-yr-old male was referred to emergency ward for flulike syndrome (fever, chills, headache, myalgia, cough, fatigue and diarrhea) from 5 days ago. He denies other symptoms, tobacco and drugs use or abuse and significant past medical history. He had total flight hours of 12120 in transportion operations.

As an expert active paramedic, he passed his necessary flight crew annual aeromedical check-up 176 days ago, successfully.

\section{Results}

Due to COVID-19 pandemic and many hours on-the-job close contact with suspected and definitive cases, his nasopharyngeal specimen was tested for reverse transcription-polymerase chain reaction (RT-PCR) and its result was positive. Chest CT scan showed multiple bilateral ground glass opacities and consolidations, typical of COVID-19 pneumonia (Figure1).

He received the necessary treatment based on the national protocol for COVID-19 infection and at the end of the 2 weeks home quarantine period, on the follow up session, except of mild malaise, clinical condition was well and

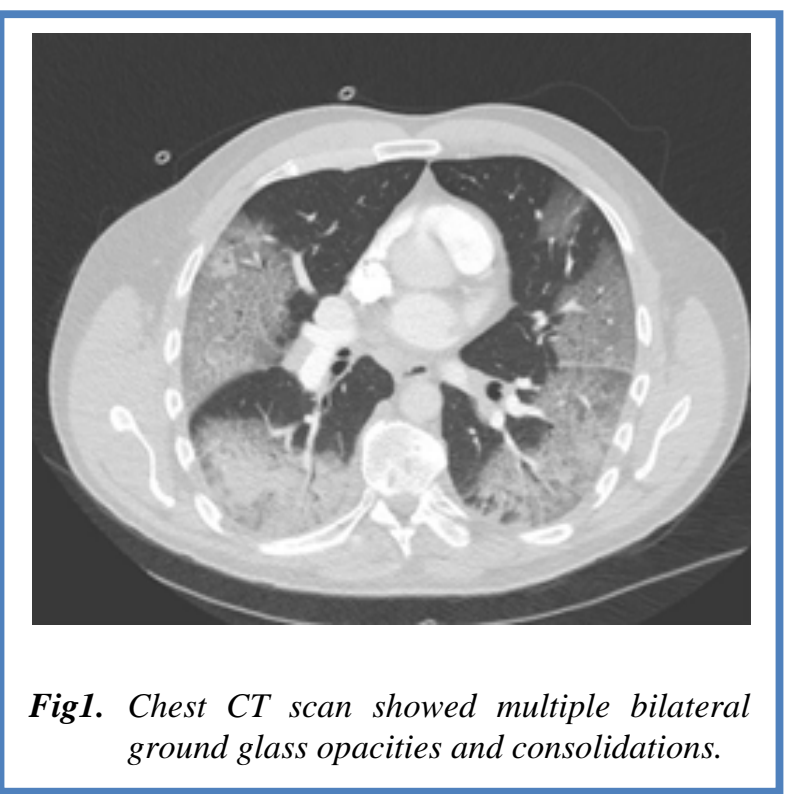


Guillain-Barré Syndrome after SARS-CoV-2 Infection

Eur J Transl Myol 31 (3): 9494, 2021 doi: 10.4081/ejtm.2021.9494

\begin{tabular}{|c|c|c|}
\hline \multicolumn{3}{|c|}{ Table.1 Significant Laboratory Findings } \\
\hline Laboratory Tests & \multicolumn{2}{|l|}{ Results } \\
\hline \multirow{5}{*}{ Arterial Blood Gas } & \multicolumn{2}{|l|}{$\mathrm{PH}=7.29$} \\
\hline & \multicolumn{2}{|c|}{ Carbon Dioxide Pressure $=47 \mathrm{mmHg}$} \\
\hline & \multicolumn{2}{|l|}{ Oxygen Pressure $=77.5 \mathrm{mmHg}$} \\
\hline & \multicolumn{2}{|l|}{ Bicarbonate $=30 \mathrm{mEq} / \mathrm{L}$} \\
\hline & \multicolumn{2}{|l|}{ Oxygen Saturation= $91 \%$} \\
\hline \multirow{7}{*}{ Haematology } & \multirow{2}{*}{ White Blood Cell = $13500 / \mu \mathrm{L}$} & Lymphocyte $=6 \%$ \\
\hline & & Neutrophil= $92 \%$ \\
\hline & \multicolumn{2}{|l|}{ Red Blood Cell = 4.000.000 / $\mu \mathrm{L}$} \\
\hline & \multicolumn{2}{|l|}{ Hemoglobin= $11.4 \mathrm{gr} / \mathrm{dL}$} \\
\hline & \multicolumn{2}{|l|}{ Hematocrit $=37.8 \%$} \\
\hline & \multicolumn{2}{|l|}{ Platelet $=120000 / \mu \mathrm{L}$} \\
\hline & \multicolumn{2}{|c|}{ Blood Culture in 3 times = No growth } \\
\hline \multirow{2}{*}{ Serology } & \multicolumn{2}{|l|}{ C-Reactive Protein $=++$} \\
\hline & \multicolumn{2}{|c|}{ Erythrocyte Sedimentation Rate $=35$} \\
\hline \multirow{3}{*}{$\begin{array}{l}\text { Cerebrospinal Fluid } \\
\text { Analysis }\end{array}$} & \multicolumn{2}{|c|}{$\begin{array}{l}\text { Reverse Transcription Polymerase Chain Reaction for } \\
\text { SARS-CoV-2 RNA = Negative }\end{array}$} \\
\hline & \multicolumn{2}{|c|}{ White Blood Cell (Predominately Lymphocyte) $=7 / \mu \mathrm{L}$} \\
\hline & \multicolumn{2}{|c|}{ Protein $=49 \mathrm{mg} / \mathrm{dL}$} \\
\hline $\begin{array}{l}\text { Cerebrospinal Fluid } \\
\text { Culture }\end{array}$ & \multicolumn{2}{|l|}{ No growth } \\
\hline
\end{tabular}

candidate to return to work soon. Few days later, he confronted a subacute onset of progressive lower limbs weakness, paresthesia and pain which rapidly evolving to a severe, flaccid paraparesis during 12 days. Neurologic examination showed normal consciousness (GCS=14) and verbal, no cranial nerves abnormality, muscles weakness with Medical Research Council score $=1 / 5$ at lower limbs, extensive stocking-and-glove hypesthesia at

Table 2. Proposed infections antecedent of Guillain-Barré syndrome

\begin{tabular}{|l|l|}
\hline Viruses & Bacteria \\
\hline Adenovirus & Brucella \\
\hline Coronavirus & Campylobacter Jejuni \\
\hline Coxsaskievirus & Haemophilus Influenza \\
\hline Cytomegalovirus & Helicobacter Pylori \\
\hline Epstein-Barr Virus & Listeria Monocytogenes \\
\cline { 1 - 1 } Echo Virus & Mycoplasma Pneumoniae \\
\cline { 1 - 1 } Hepatitis A, B, C and E & Pasteurella Tularensis \\
\cline { 1 - 1 } Herpes Simplex & Salmonella Typhosa \\
\cline { 1 - 1 } Herpes Zoster & Shigella \\
\cline { 1 - 1 } Human Herpesvirus Type 6 & \multirow{2}{*}{ Yersinia } \\
\cline { 1 - 1 } Influenza A and B & \\
\cline { 1 - 1 } Japanese Encephalitis Virus & \\
\cline { 1 - 1 } Measles & \\
\cline { 1 - 1 } Mumps &
\end{tabular}


the both legs, absent deep tendon reflexes and normal plantar response, symmetrically. Mild dyspnea, moderate pain (pain scoring $=6 / 10$ ) in low back and severe paresthesia in both legs were the important patient's complains. Urgent assessment findings included: normal brain and spinal CT scan, absence of both sural nerve sensory action potential (SAP) and the tibial nerve compound muscle action potential (CMAP), increased common peroneal CMAP distal latency, decreased velocity, severely decreased CMAP amplitude for the same nerve on electroneurography. Significant laboratory findings are summarized in Table 1.

These findings indicated a moderate to severe form of acute polyradiculoneuritis with prominent demyelinating features and represented diagnosis of Guillain-Barré syndrome (GBS) associated with COVID-19 infection. Because of the possibility of sudden respiratory deterioration and need for endotracheal intubation and ventilation support, he was admitted at intensive care unit (ICU) and high-flow oxygen (70-80\%) via nonrebreather bag mask. High-dose intravenous immunoglobulins $(0.5 \mathrm{~g} / \mathrm{kg} / \mathrm{d}$ for 5 days) were started immediately.

Despite rapid and effective diagnosis and treatment about a month after the onset of therapeutic measures with no need to ventilation support, significant improvement in sensory-motor abnormalities begun, but complete recovery was not achievd. Due to the recurring and disabling nature of GBS and its therapeutic complications, the final decision to return to his flight service, as a flight crew, requires more time and more thorough follow-up, but will likely never be released.

\section{Discussion}

GBS is a typical post-infectious disorder and two-thirds of adult patients report preceding symptoms of a respiratory or gastrointestinal tract infection within 2-4 weeks of onset of weakness. ${ }^{6}$ Proposed antecedent infections associated with GBS are listed in Table 2. ${ }^{7}$

Cases of GBS have also been reported shortly after vaccination with rabies vaccine and various types of influenza A virus vaccine. ${ }^{8}$ Extra respiratory multisystemic involvement of SARS-CoV-2 has also been reported and neurological manifestations are not common but reported during the acute phase and treatment period., ${ }^{1,2}$ In particular, COVID-19 is a neurotrophic, neuroinvasive, and neuroinflammatory virus. Experimental animal studies reported that they cause acute flaccid paralysis (AFP) and demyelination. ${ }^{9,10}$ Recently, a case of Acute Myelitis after SARS-CoV-2 infection was reported, too. ${ }^{11}$

In onclusion, we reported a possible correlation between acute COVID-19 infection and GBS, a condition that in recent years has been linked to other emergent microbial infections. This interesting and rare COVID-19 neurological complication is important reminding our colleagues that diagnosis and treatment of COVID-19 infection is not a brief process, but it is only the beginning of a long road. The authors believe that, these days, accurate continuous evaluation and follow-up of patients is the missed ring in fighting chain of COVID-19 pandemic.

\section{List of acronyms}

CMAP - compound muscle action potential

COVID-19 - Coronavirus disease 19

GBS - Guillain-Barré syndrome

GCS - Glasgow Coma Scale

ICU - intensive care unit

RT-PCR - reverse transcription-polymerase chain reaction

SAP - sensory action potential

SARS-CoV-2 - Severe acute respiratory corona virus 2 CoV-2 - Coronavirus 2

\section{Authors contributions}

MD,HS, and AAF conceived and designed the experiments, performed the data analyses and wrote the paper. All authors have read and approved the typescript.

\section{Acknowledgments}

None.

\section{Funding}

None.

\section{Conflict of Interest}

The author declares no competing interests.

\section{Ethical Publication Statement}

We confirm that we have read the Journal's position on issues involved in ethical publication and affirm that this report is consistent with those guidelines.

\section{Corresponding Author}

Hamze Shahali, Assistant Professor and Head of the Aerospace and Sub-Aquatic Medical Faculty, Aja University of Medical Sciences, West Fatemi St, Tehran, Iran. Postal Code: 1411718541 Tel: +989121952804 ORCID iD: 0000-0003-0761-6599

E-mail: hamze.shahali@ajaums.ac.ir

E-mails and ORCID iDs of Coauthors

Mohammad Darvishi: darvishi1349@gmail.com

ORCID iD: 0000-0003-0332-2489

Azade Amirabadi Farahani:

ORCID iD: 0000-0002-4694-9268

$$
\text { amirabadi.azade@gmail.com }
$$

\section{References}

1. Casadevall A, Pirofski LA. The convalescent sera option for containing COVID-19. J Clin Invest. 2020 Apr 1;130(4):1545-1548. doi: 10.1172/ JCI138003.

2. Wang D, Hu B, Hu C, Zhu F, Liu X, Zhang J, Wang B, Xiang H, Cheng Z, Xiong Y, Zhao Y, Li Y, Wang X, Peng Z. Clinical Characteristics of 138 


\section{Guillain-Barré Syndrome after SARS-CoV-2 Infection}

Eur J Transl Myol 31 (3): 9494, 2021 doi: 10.4081/ejtm.2021.9494

Hospitalized Patients With 2019 Novel Coronavirus-Infected Pneumonia in Wuhan, China. JAMA. 2020 Mar 17;323(11):1061-1069. doi: 10.1001/jama.2020.1585. Erratum in: JAMA. 2021 Mar 16;325(11):1113.

3. Li YC, Bai WZ, Hashikawa T. The neuroinvasive potential of SARS-CoV2 may play a role in the respiratory failure of COVID-19 patients. J Med Virol. 2020 Jun;92(6):552-555. doi: 10.1002/jmv.25728. Epub 2020 Mar 11.

4. Alberti P, Beretta S, Piatti M, Karantzoulis A, Piatti ML, Santoro P, Viganò M, Giovannelli G, Pirro F, Montisano DA, Appollonio I, Ferrarese C. GuillainBarré syndrome related to COVID-19 infection. Neurol Neuroimmunol Neuroinflamm. 2020 Apr 29;7(4):e741. doi: 10.1212/NXI.0000000000000 741.

5. Karimi N, Sedaghat Z. Letter to the editor. Concerning the article entitled "Guillain Barre syndrome associated with COVID-19 infection: A case report". J Clin Neurosci. 2020 Sep;79:257-258. doi: 10.1016/j.jocn.2020.06.025. Epub 2020 Jul 4.

6. Jacobs BC, Rothbarth PH, van der Meché FG, Herbrink P, Schmitz PI, de Klerk MA, van Doorn PA. The spectrum of antecedent infections in Guillain-Barré syndrome: a case-control study. Neurology. 1998 Oct;51(4):1110-5. doi: 10.1212/wnl.51.4.1110.

7. Mcgrath TM. Infections of the Central Nervous System, 4th edn. Chap 20. Guillain-Barré
Syndrome. Accessed via https://doctorlib. info/ infectiology/infections-central-nervoussystem/21.html.

8. Schonberger LB, Bregman DJ, Sullivan-Bolyai JZ, Keenlyside RA, Ziegler DW, Retailliau HF, Eddins DL, Bryan JA. Guillain-Barre syndrome following vaccination in the National Influenza Immunization Program, United States, 1976--1977. Am J Epidemiol. 1979 Aug;110(2):105-23. doi: 10.1093/oxfordjournals.aje.a1127953.

9. Brison E, Jacomy $\mathrm{H}$, Desforges $\mathrm{M}$, Talbot PJ. Glutamate excitotoxicity is involved in the induction of paralysis in mice after infection by a human coronavirus with a single point mutation in its spike protein. J Virol. 2011 Dec;85(23):1246473. doi: 10.1128/JVI.05576-11. Epub 2011 Sep 28.

10. Zhao K, Huang J, Dai D, Feng Y, Liu L, Nie S. Acute myelitis after SARS-CoV-2 infection: a case report. medRxiv preprint. Mar 2020. https://doi.org/10.1101/2020.03.16.20035105.

11. Ashrafi MR, Azizimalamiri R, Shervin Badv R, Tavasoli AR, Nikkhah A, Montazerlotfelahi H, et al. Coronavirus, Its Neurologic Manifestations, and Complications. Iran J Pediatr. 2020 April; 30(2):e102569. doi: 10.5812/ijp.102569.

Submitted: November 12, 2020

Revision received: April 29, 2021 Accepted for publication: May 8, 2021 